\title{
PENGARUH GAYA KEPEMIMPINAN TRANSFORMASIONAL, KOMPENSASI DAN BUDAYA ORGANISASI TERHADAP PRODUKTIVITAS KERJA KARYAWAN ( Studi Kasus Pada Perhimpunan BMT Indonesia di Kabupaten Semarang )
}

Oleh:

Andi Setyawan Suyitno

Alumni STIE AMA Salatiga

Hardi Utomo

Dosen Tetap STIE AMA Salatiga

\begin{abstract}
Abstrak
Di dalam perusahaan, sumber daya manusia adalah asset utama dalam setiap berjalannya suatu kegiatan. Oleh karena itu hendaknya organisasi memberikan arahan yang positif demi tercapainya tujuan organisasi.

Tujuan penelitian ini adalah untuk menguji pengaruh kepemimpinan transformasional, kompensasi dan budaya organisasi terhadap produktivitas kerja karyawan Perhimpunan BMT Indonesia di Kabupaten Semarang. Jumlah sampel dalam penelitian ini adalah 66 orang. Untuk menjawab tujuan penelitian yang telah ditetapkan maka data di analisis dengan mengunakan analisa regresi linier berganda. Untuk mengetahui diterima atau ditolaknya hipotesis yang diujikan dalam penelitian ini digunakan uji $t$ dan $F$. Untuk mengatahui prosentase variabel dependen yang disebabkan oleh variabel Indepanden maka digunakan koefisien determinasi. Dari uji regresi linier berganda didapatkan persamaan $Y=-0,812+0,063 X_{1}+0,157 X_{2}+$ $0,393 X_{3}$ Untuk uji $t$ variabel gaya kepemimpinan transformasional $\left(X_{1}\right)$ tidak memiliki pengaruh yang signifikan tehadap produktivitas kerja karyawan (Y), dibuktikan dengan $t$ hitung $(0,673)<t_{\text {tabel }}(1,999)$ dengan sig. 0,504 $>0,05$. Variabel kompensasi $\left(\mathrm{X}_{2}\right)$ tidak memiliki pengaruh yang signifikan terhadap produktivitas kerja karyawan $(Y)$ dibuktikan dengan nilai $t_{\text {hitung }}(1,129)<t_{\text {tabel }}(1,999)$ dengan sig. 0,263 $>0,05$. Variabel budaya organisasi $\left(X_{3}\right)$ memiliki pengaruh yang signifikan terhadap produktivitas kerja karyawan $(Y)$, dibuktikan dengan nilai $t$ hitung $(3,153)>t$ tabel $(1,999)$ dengan sig. 0,002 <0,05. Uji $F$ diperoleh hasil $F_{\text {hitung }}(11,142)>F_{\text {tabel }}(2,75)$, hal ini berarti bahwa secara simultan terdapat pengaruh yang signifikan antara variabel kepemimpinan transformasional $\left(X_{1}\right)$, kompensasi $\left(X_{2}\right)$ dan budaya organisasi $\left(X_{3}\right)$ terhadap produktivitas kerja karyawan $(Y)$. Sehingga hipotesis yang menyatakan ada pengaruh antara variabel independen terhadap variabel dependen adalah terbukti. Hasil uji koefisien determinasi didapatkan nilai Adjusted $R^{2}=0,319$ yang menunjukkan bahwa 31,9\% variabel produktivitas kerja pada perhimpunan BMT Indonesia di Kabupaten Semarang dipengaruhi oleh ketiga variabel (kepemimpinan transformasional, kompensasi, dan budaya organisasi), sedangkan sisanya sebesar $100 \%-31,9 \%=68,1 \%$ dipengaruhi oleh variabel independen lainnya diluar penelitian.
\end{abstract}

Kata kunci : kepemimpinan transformasional, kompensasi, budaya organisasi, produktivitas kerja karyawan

Pengaruh Gaya Kepemimpinan Transformasional, Kompensasi

Dan Budaya Organisasi Terhadap Produktivitas Kerja Karyawan

( Studi Kasus Pada Perhimpunan Bmt Indonesia Di Kabupaten Semarang )

(Andi Setyawan Suyitno \& Hardi Utomo) 


\section{PENDAHULUAN}

Koperasi Syariah atau yang lebih dikenal dengan nama BMT (Baitul Maal wat Tamwil) adalah sebuah lembaga keuangan yang mendasarkan semua kegiatannya berdasar prinsip syariah. Baik dalam hal budaya kerja, sistem atau pun akad - akadnya (perjanjiannya).

BMT lebih mengarah pada kegiatan Usaha Simpan Pinjam Syariah, bukan ke usaha yang lain. Jadi kebanyakan BMT, hanya memiliki 1 (satu) unit usaha, yaitu simpan pinjam syariah, yang sekarang diperluas menjadi Simpan Pinjam dan Pembiayaan Syariah sesuai Permen terbaru yang dikeluarkan oleh Menteri Koperasi dan UKM tentang Kelembagaan Koperasi, yaitu Permen nomor 10 tahun 2015. Perhimpunan BMT Indonesia atau yang lebih dikenal dengan singkatan PBMTI, adalah sebuah lembaga/organisasi massa tempat berkumpulnya BMT - BMT yang menjadi anggotanya. Berawal dengan nama BMT CENTER di tahun 2005, pada akhirnya berubah nama menjadi Perhimpunan BMT Indonesia karena beberapa alasan.

Tantangan utama dalam manajemen sumber daya manusia di suatu perusahaaan salah satunya adalah bagaimana meningkatkan produktivitas kerja kayawan. Dalam usaha peningkatan produktivitas kerja kayawan serta pengembangan SDM perlu adanya program-program manajemen sumber daya manusia seperti analisis jabatan, seleksi yang baik, perencanaan karier, penggajian, orientasi, gaya kepemimpinan dan lain-lain. Dengan produktivitas kerja kayawan yang baik di harapkan karyawan mampu mewujudkan tujuan dari perusahaan tersebut.

Kepemimpinan transformasional yaitu pemimpin yang mencurahkan perhatiannya kepada persoalan-persoalan yang dihadapi oleh para pengikutnya dan kebutuhan pengembangan dari masing-masing pengikutnya dengan cara memberikan semangat dan dorongan untuk mencapai tujuannya. (Robbin, 2007:473).

Kompensasi menurut (Mirahot Tua E, 2007:244) adalah keseluruhan balas jasa yang diterima oleh pegawai sebagai akibat dari pelaksanaan pekerjaan di 
organisasi dalam bentuk uang atau lainnya, yang dapat berupa gaji, upah, bonus, insentif, dan tunjangan lainnya seperti tunjangan kesehatan, tunjangan hari raya, uang makan, uang cuti, dan lain-lain. Kompensasi acapkali juga disebut penghargaan dan dapat di definisikan sebagai setiap bentuk penghargaan yang diberikan kepada karyawan sebagai balas jasa atas kontribusi yang mereka berikan kepada organisasi (Mutiara S. Panggabean, 2004:75).

Budaya organisasi merupakan norma, nilai-nilai, asumsi, kepercayaan, filsafat, kebiasaan organisasi, dan sebagainya (isi budaya organisasi) yang dikembangkan dalam waktu yang lama oleh pendiri, pemimpin, dan anggota organisasi yang disosialisasikan dan diajarkan kepada anggota baru serta diterapkan dalam aktivitas organisasi sehingga mengaruh pada pola pikir, sikap, dan perilaku anggota organisasi dalam memproduksi produk, melayani para konsumen, dan mencapai tujuan organisasi (Wirawan, 2007 : 10).

Dalam doktrin pada konferensi Oslo, 1984, yang dikutip Muchdarsyah (2003:17), tercantum definisi produktivitas yaitu: "Produktivitas adalah suatu konsep yang bersifat universal yang bertujuan untuk menyediakan lebih banyak barang dan jasa untuk lebih banyak manusia, dengan menggunakan sumbersumber riil yang makin sedikit".

Obyek penelitian adalah para pimpinan di BMT masing-masing, untuk variabel gaya kepemimpinan transformasional, yang kami lihat dan amati semenjak awal berdiri tahun 1998, tipe gaya kepemimpinan yang dikembangkan dan dilatih sejak awal adalah pendekatan gaya kepemimpinan transformasional. Untuk variabel kompensasi, walau masing-masing BMT memiliki standar gaji/kompensasi masing-masing, akan tetapi baku dari standar penggajian adalah sama, menggunakan standar gaji seperti yang diberikan dalam standar gaji dalam SOP (Standar Operasional Prosedur) Perhimpunan BMT Indonesia yang tertera dalam buku P4 Insan BMT (Pedoman Perencanaan Pengelolaan dan Pengembangan Insan BMT). Begitu pula untuk budaya organisasi, walaupun masing-masing BMT mengembangkan gaya masing-masing, akan tetapi baku dari budaya organisasi BMT-BMT anggota Perhimpunan BMT Indonesia di 
Kabupaten Semarang hampir sama, sesuai dengan apa yang dilatihkan sejak awal dahulu.

\section{Rumusan Masalah}

Berdasarkan apa yang diuraikan dalam latar belakang tersebut diatas, maka dapat ditarik rumusan masalah pada penelitian ini sebagai berikut :

1. Adakah pengaruh gaya kepemimpinan transformasional terhadap produktivitas kerja karyawan pada Perhimpunan BMT Indonesia di Kabupaten Semarang?

2. Adakah pengaruh kompensasi terhadap produktivitas kerja karyawan pada Perhimpunan BMT Indonesia di Kabupaten Semarang?

3. Adakah pengaruh budaya organisasi terhadap produktivitas kerja karyawan pada Perhimpunan BMT Indonesia di Kabupaten Semarang?

4. Adakah pengaruh gaya kepemimpinan transformasional, kompensasi, dan budaya organisasi secara simultan terhadap produktivitas kerja karyawan pada Perhimpunan BMT Indonesia di Kabupaten Semarang?

\section{Tujuan Dan Manfaat Penelitian}

\section{Tujuan penelitian}

Berdasarkan pada rumusan masalah di atas, maka tujuan yang ingin dicapai dalam penelitian ini adalah sebagai berikut :

a. Untuk mengetahui pengaruh antara gaya kepemimpinan transformasional terhadap produktivitas kerja karyawan pada Perhimpunan BMT Indonesia di Kabupaten Semarang.

b. Untuk mengetahui pengaruh antara kompensasi terhadap produktivitas kerja karyawan pada Perhimpunan BMT Indonesia di Kabupaten Semarang.

c. Untuk mengetahui pengaruh antara budaya organisasi terhadap produktivitas kerja karyawan pada Perhimpunan BMT Indonesia di Kabupaten Semarang.

d. Untuk mengetahui pengaruh gaya kepemimpinan transformasional, kompensasi, dan budaya organisasi secara simultan terhadap 
produktivitas kerja karyawan pada Perhimpunan BMT Indonesia di Kabupaten Semarang.

\section{Manfaat penelitian}

Manfaat yang ingin diperoleh dari penelitian yang penulis lakukan adalah:

a. Bagi Penulis

Penelitian ini dapat menambah pengetahuan dan melatih kemampuan penulis dalam menganalisa persoalan berdasarkan teori yang diperoleh di bangku kuliah dengan kenyataan yang ada di bidang manajemen sumber daya manusia terutama pada peningkatan produktivitas kerja karyawan.

b. Bagi Perhimpunan BMT Indonesia di Kabupaten Semarang.

Hasil penelitian ini diharapkan dapat dijadikan sebagai masukan ataupun pertimbangan dalam upaya meningkatkan produktivitas kerja karyawan utamanya berkaitan dengan gaya kepemimpinan transformasional, kompensasi, dan budaya organisasi pada karyawan Perhimpunan BMT Indonesia di Kabupaten Semarang.

c. Bagi STIE AMA Salatiga

Dapat menambah referensi dan wawasan mengenai pengaruh gaya kepemimpinan transformasional, kompensasi, dan budaya organisasi terhadap kinerja karyawan.

\section{PAPARAN TEORITIS}

\section{Gaya kepemimpinan transformasional}

Kepemimpinan transformasional merupakan kemampuan individu untuk mempengaruhi, memotivasi dan memungkinkan pengikut untuk memberikan kontribusi terhadap efektivitas dan kesuksesan organisasi. Tingkat sejauh mana seorang pemimpin disebut transformasional terutama diukur dalam hubungannya dengan efek kepemimpinan transformasional tersebut terhadap para pengikut. Para pengikut seorang pemimpin transformasional merasa adanya kepercayaan, kekaguman, kesetiaan dan hormat terhadap pemimpin 
tersebut dan mereka merasa termotivasi untuk melakukan lebih dari pada yang awalnya diharapkan oleh mereka.

Bass (dalam Wutun, 2001, h.350), juga menyatakan bahwa gaya kepemimpinan transformasional cenderung membangun kesadaran para bawahannya mengenai pentingnya nilai kerja dan tugas mereka. Pemimpin berusaha memperluas dan meningkatkan kebutuhan melebihi minat pribadi serta mendorong perubahan tersebut ke arah kepentingan bersama termasuk kepentingan organisasi (Wutun, 2001, h.352).

Menurut Yammarino dan Bass (1990, dalam Daryanto, 2005) pemimpin transformasional merupakan pemimpin yang karismatik dan mempunyai peran sentral dan strategis dalam membawa organisasi mencapai tujuannya. Pemimpin transformasional juga mempunyai kemampuan untuk menyamakan visi masa depan dengan bawahannya, serta meningkatkan kebutuhan bawahan pada tingkat yang lebih tinggi dari pada apa yang mereka butuhkan. Pemimpin transformasional harus mampu membujuk para bawahannya melakukan tugastugas mereka melebihi kepentingan mereka sendiri demi kepentingan organisasi yang lebih besar. Pemimpin transformasional juga akan berusaha mengartikulasikan visi masa depan organisasi yang realistik, menstimulasi bawahan dengan cara yang intelektual, dan menaruh perhatian pada perbedaan-perbedaan yang dimiliki oleh bawahannya. Dengan kepemimpinan transformasional, para pengikut merasakan kepercayaan, kekaguman, kesetiaan dan penghormatan terhadap pemimpin, dan mereka termotivasi untuk melakukan lebih daripada yang awalnya diharapkan dari mereka.

Bass (1990, dalam Harsiwi, 2005) mengemukakan bahwa kepemimpinan transformasional mempunyai empat dimensi, yaitu:

1. attributed charisma.

2. inspirational motivation (motivasi inspirasi).

3. intellectual stimulation (stimulasi intelektual).

4. individualized consideration (konsiderasi individu).

Menurut Bass dan Avolio (1990, dalam Suryanto, 2005) menemukan bahwa kepemimpinan transformasional memiliki empat komponen perilaku, yaitu: 
1. Idealized Influence

2. Individualized Consideration

3. Inspirational Motivation

4. Intellectual Stimulation

Sedangkan menurut Wutun (2001, h.353) kepemimpinan transformasional memiliki lima aspek yaitu :
a. Atributed Charisma
b. Idealized Influence
c. Inspirational Motivation
d. Intelectual Stimulation
e. Individualized Consideration

\section{Kompensasi}

Kompensasi adalah keseluruhan balas jasa yang diterima oleh pegawai sebagai akibat dari pelaksanaan pekerjaan di organisasi dalam bentuk uang atau lainnya, yang dapat berupa gaji, upah, bonus, insentif, dan tunjangan lainnya seperti tunjangan kesehatan, tunjangan hari raya, uang makan, uang cuti, dan lain-lain." (Mirahot Tua E, 244:2007). Menurut Mutiara S. Panggabean (2004:81) tinggi rendahnya kompensasi di pengaruhi oleh faktor:
a. Penawaran dan permintaan,
b. Serikat pekerja,
c. Kemampuan untuk membayar,
d. Produktivitas,
e. Biaya hidup, dan
f. pemerintah

Menurut Veithzal Rivai (2009:744) komponen-komponen kompensasi terdiri dari:
a. Gaji
b. Insentif
c. Kompensasi tidak langsung (fringe benefit) 


\section{Budaya organisasi}

Budaya organisasi merupakan norma, nilai - nilai, asumsi, kepercayaan, filsafat, kebiasaan organisasi, dan sebagainya (isi budaya organisasi) yang dikembangkan dalam waktu yang lama oleh pendiri, pemimpin, dan anggota organisasi yang disosialisasikan dan diajarkan kepada anggota baru serta diterapkan dalam aktivitas organisasi sehingga mengaruh pada pola pikir, sikap, dan perilaku anggota organisasi dalam memproduksi produk, melayani para konsumen, dan mencapai tujuan organisasi (Wirawan, 2007 : 10).

Budaya organisasi yang kuat menjadi mekanisme control dan menjadi rasional yang memandu dan membentuk sikap serta perilaku para karyawan sehingga sangat mempengaruhi kinerja, seperti yang di kemukakan oleh Robbins (2006:18) melalui beberapa indikator seperti:

1) Pengarahan.

2) Inisiatif

3) Ketulusan

4) Integritas

5) Pola komunikasi

\section{Produktivitas}

Dalam doktrin pada konferensi Oslo, 1984, yang dikutip Muchdarsyah (2003:17), tercantum definisi produktivitas adalah suatu konsep yang bersifat universal yang bertujuan untuk menyediakan lebih banyak barang dan jasa untuk lebih banyak manusia, dengan menggunakan sumber-sumber riil yang makin sedikit.

Menurut Muchdarsyah (2003: 23) secara umum pengukuran produktivitas berarti perbandingan-perbandingan yang dapat dibedakan dalam tiga jenis yang sangat berbeda:

a. Perbandingan-perbandingan antara pelaksanaan sekarang dengan pelaksanaan secara historis yang tidak menunjukkan apakah pelaksanaan sekarang ini memuaskan namun hanya dengan mengetengahkan apakah meningkat atau berkurang serta tingkatannya. 
b. Perbandingan pelaksanaan antara satu unit (perorangan tugas, seksi, proses) dengan lainnya. Pengukuran seperti itu menunjukkan pencapaian relatif.

c. Perbandingan pelaksanaan sekarang dengan targetnya dan inilah yang terbaik sebagai memusatkan perhatian pada sasaran atau tujuan.

Menurut Henry Simamora (2004:612) faktor-faktor yang digunakan dalam mengukur produktivitas kerja karyawan meliputi kuantitas kerja, kualitas kerja, dan ketepatan waktu.

Menurut Muchdarsyah Sinungan (2003:126) manfaat dari pengukuran produktivitas kerja kayawan adalah sebagai berikut :

a. Umpan balik pelaksanaan kerja untuk memperbaiki produktivitas karyawan.

b. Evaluasi produktivitas kerja kayawan digunakan untuk penyelesaian misalnya: pemberian bonus dan bentuk kompensasi lainnya.

c. Untuk keputusan-keputusan penetapan, misalnya promosi, transfer, dan demosi.

d. Untuk kebutuhan latihan dan pengembangan.

e. Untuk perencanaan dan pengembangan karier.

f. Untuk mengetahui penyimpangan-penyimpangan proses staffing.

g. Untuk mengetahui ketidakakuratan informal.

h. Untuk memberikan kesempatan kerja yang adil.

\section{Kerangka Pemikiran}

Penelitian ini terdiri dari satu variabel terikat yaitu produktivitas kerja karyawan dan tiga variabel bebas yaitu gaya kepemimpinan transformasional, kompensasi. dan budaya organisasi. Selanjutnya ketiga variabel tersebut diduga mempengaruhi produktivitas karyawan. 


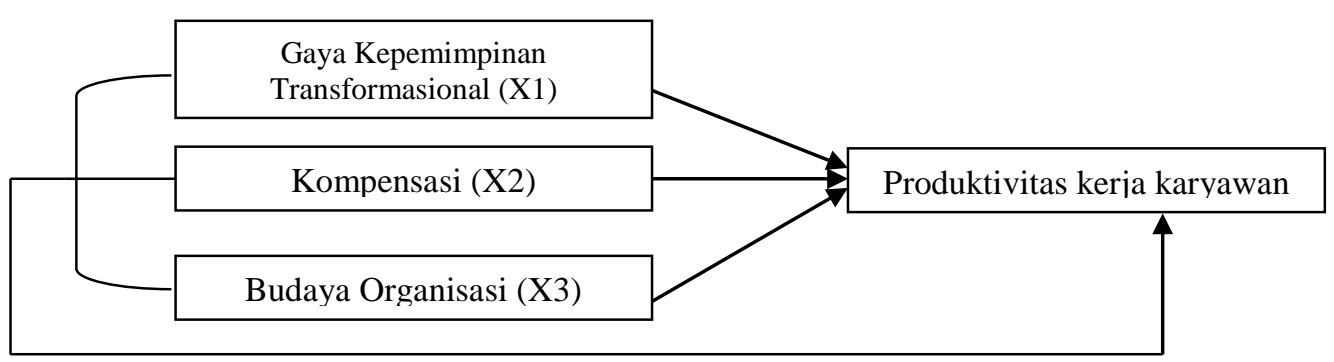

Gambar 1

Model Kerangka Pemikiran

\section{Hipotesis}

Sugiyono (2006:51) menjelaskan bahwa hipotesis adalah suatu jawaban sementara terhadap rumusan masalah penelitian, oleh karena itu rumusan masalah penelitian biasanya disusun dalam kalimat pertanyaan. Dikatakan sementara, karena jawaban yang diberikan baru didasarkan pada teori yang relevan, belum didasarkan pada fakta-fakta empiris yang diperoleh melalui pengumpulan data.

Hipotesis dalam penelitian ini adalah sebagai berikut :

1. Ada pengaruh signifikan gaya kepemimpinan transformasional terhadap produktivitas kerja karyawan pada Perhimpunan BMT Indonesia di Kabupaten Semarang.

2. Ada pengaruh signifikan kompensasi terhadap produktivitas kerja karyawan pada Perhimpunan BMT Indonesia di Kabupaten Semarang.

3. Ada pengaruh signifikan budaya organisasi terhadap produktivitas kerja karyawan pada Perhimpunan BMT Indonesia di Kabupaten Semarang.

4. Ada pengaruh signifikan gaya kepemimpinan transformasional, kompensasi, dan budaya organisasi secara simultan terhadap produktivitas kerja karyawan pada Perhimpunan BMT Indonesia di Kabupaten Semarang.

\section{METODE PENELITIAN}

\section{Populasi dan sampel}

\section{a. Populasi}

Populasi dalam penelitian ini adalah seluruh karyawan pada Perhimpunan BMT Indonesia di Kabupaten Semarang yang berjumlah 190 orang. 


\section{b. Sampel}

Dalam penelitian ini menggunakan rumus Slovin (Umar Husein, 2003:108). Berdasarkan rumus tersebut diperoleh sampel 66 orang responden, berikut uraiannya :

$$
\begin{aligned}
\mathrm{n} & =\frac{\mathrm{N}}{1+\left(\mathrm{Ne}^{2}\right)}=\frac{190}{1+\left(190 \times 0,1^{2}\right)} \\
& =65,5172414
\end{aligned}
$$

Dengan demikian jumlah sampel yang diambil dalam penelitian ini adalah 66 orang karyawan pada BMT-BMT anggota Perhimpunan BMT Indonesia di Kabupaten Semarang, dengan perincian sebagai berikut :

Tabel 1

\begin{tabular}{|c|c|c|c|}
\hline No. & Nama BMT & $\begin{array}{c}\text { Jumlah } \\
\text { Karyawan }\end{array}$ & $\begin{array}{c}\text { Jumlah } \\
\text { Sampling }\end{array}$ \\
\hline 1 & BMT Al Fattah & 7 & 3 \\
\hline 2 & BMT Al Hikmah & 35 & 12 \\
\hline 3 & BMT Al Mu'aawanah & 10 & 4 \\
\hline 4 & BMT Amal Mulia & 22 & 8 \\
\hline 5 & BMT Assaadah & 8 & 3 \\
\hline 6 & BMT Atina & 4 & 2 \\
\hline 7 & BMT Bina Insani & 15 & 0 \\
\hline 8 & BMT Bina Usaha & 9 & 3 \\
\hline 9 & BMT Blater & 5 & 2 \\
\hline 10 & BMT Hubbul Wathon & 21 & 7 \\
\hline 11 & KJKS Inti Muamalat & 15 & 7 \\
\hline 12 & BMT Mandiri & 12 & 4 \\
\hline 13 & BMT Mandiri Sejahtera & 15 & 7 \\
\hline 14 & BMT Sumber Mulia & 12 & 4 \\
\hline \multicolumn{2}{|r|}{ Jumlah } & 190 & 66 \\
\hline
\end{tabular}

Sebaran Responden 


\section{b. Definisi Operasional}

Indikator gaya kepemimpinan transformasional menurut Bass dan Avolio (1990, dalam Suryanto, 2005) memiliki empat komponen perilaku:

1) Idealized Influence

2) Individualized Consideration

3) Inspirational Motivation

4) Intellectual Stimulation

Indikator Kompensasi (Veithzal Rivai, 2009:744) :

1) Gaji

2) Insentif

3) Kompensasi tidak langsung

Indikator Budaya Organisasi menurut Robbins (2006:18):

1) Pengarahan

2) Inisiatif

3) Ketulusan

4) Integritas

5) Pola komunikasi

Indikator Produktivitas (Muchdarsyah Sinungan, 2003:23):

1) Perbandingan-perbandingan antara pelaksanaan sekarang dengan pelaksanaan secara historis

2) Perbandingan pelaksanaan antara satu unit (perorangan tugas, seksi, proses) dengan lainnya

3) Perbandingan pelaksanaan sekarang dengan targetnya

\section{Metode Analisis Data}

\section{a. Uji Validitas}

Validitas adalah suatu ukuran yang menunjukan tingkat kevalidan atau kesahihan suatu instrument. Suatu instrument yang valid atau sahih mempunyai validitas yang tinggi. Instrument yang kurang valid berarti memiliki validitas rendah. (Arikunto, 2006: 168)

Cara yang digunakan adalah dengan analisis item (corrected item to total corelation), dimana setiap nilai yang ada pada setiap butir pertanyaan dikorelasikan dengan total nilai seluruh butir pertanyaan 
suatu variabel, kemudian dibandingkan dengan $\mathrm{r}$ tabel. Syarat minimum untuk dianggap valid adalah $\mathrm{r}$ hitung $>$ dari $\mathrm{r}$ tabel.

Dalam penelitian ini menggunakan taraf signifikasi 0,05 yang merupakan ukuran standar yang sering digunakan dalam penelitian. Untuk mengetahui $r$ tabel digunakan rumus $\mathrm{df}=\mathrm{n}-2$, dimana $\mathrm{n}$ adalah jumlah sampel dengan degree of freedom sebesar $5 \%$ atau $\alpha / 2$ pada tabel. Dengan taraf signifikan $95 \%$ kriteria pengujian valid apabila :
a. $\quad r_{\text {hitung }}>r_{\text {tabel }}$ berarti pengujian dikatakan valid
b. $\quad r_{\text {hitung }} \leq r_{\text {tabel }}$ berarti pengujian dikatakan tidak valid.

\section{b. Uji Reliabilitas}

Menurut Iqbal Hasan (2002:77), Reliabilitas adalah tingkat ketepatan, ketelitian dan keakuratan sebuah instrument. Jadi reliabilitas menunjukan apakah instrument tersebut secara konsisten memberikan hasil ukuran yang sama tentang sesuatu yang diukur pada waktu yang berlainan. Rumus untuk menghitung koefisien reliabilitas instrument dengan menggunakan Cronbach Alpha

Dengan taraf signifikan $95 \%$ kriteria pengujian reliable jika :

1) $\mathrm{r}$ alpha positif dan $\mathrm{r}$ alpha $\geq 0,6$, maka konstruk atau variable dikatakan reliabel.

2) $\mathrm{r}$ alpha negatif atau $\mathrm{r}$ alpha $\leq 0,6$, maka suatu variabel dikatakan tidak reliabel.

\section{c. Uji Regresi Linier Berganda}

Sugiono (2006:257) menyebutkan persamaan Analisis Regresi Berganda untuk beberapa prediktor :

$$
\mathbf{Y}=\mathbf{a}+\mathbf{b}_{1} \mathbf{X}_{1}+\mathbf{b}_{2} \mathbf{X}_{2}+\mathbf{b}_{3} \mathbf{X}_{3}
$$

Dimana :

$\mathrm{Y} \quad=$ produktivitas kerja karyawan

a = nilai konstanta

$\mathrm{b}_{1 \ldots 3}=$ nilai variabel 
$\mathrm{X}_{1} \quad=$ variabel gaya kepemimpinan transformasional,

$\mathrm{X}_{2} \quad=$ variabel kompensasi

$\mathrm{X}_{3} \quad$ = variabel budaya organisasi

\section{d. Uji t}

Uji t digunakan untuk menguji kebenaran pernyataan hipotesis I, II, III, dan IV penelitian. Berikut prosedur uji statistiknya adalah sebagai berikut: (Hasan, Iqbal, 2004:108)

a. Menentukan formulasi hipotesis

1) $\mathrm{H}_{0}: \mathrm{b}_{1}, \mathrm{~b}_{2}, \mathrm{~b}_{3},=0$, berarti terdapat pengaruh yang signifikan antara gaya kepemimpinan transformasional (X1), kompensasi (X2), dan budaya organisasi (X3), terhadap produktivitas kerja karyawan (Y) secara parsial (individu).

2) $\mathrm{H}_{\mathrm{a}}: \mathrm{b}_{1}, \mathrm{~b}_{2}, \mathrm{~b}_{3}, \neq 0$, berarti tidak terdapat pengaruh yang signifikan antara gaya kepemimpinan transformasional (X1), kompensasi (X2), dan budaya organisasi (X3), terhadap produktivitas kerja karyawan (Y) secara parsial (individu)

b. Uji F

Uji F digunakan untuk menguji kebenaran pernyataan hipotesis IV penelitian. Berikut prosedur uji statistiknya adalah sebagai berikut: (Hasan, Iqbal, 2004 : 107)

a) Menentukan formulasi hipotesis

(1) $\mathrm{H}_{0}: \mathrm{b}_{1}, \mathrm{~b}_{2}, \mathrm{~b}_{3},<0$ berarti tidak terdapat pengaruh antara gaya kepemimpinan transformasional (X1), kompensasi (X2), dan budaya organisasi (X3), terhadap produktivitas kerja karyawan (Y) secara simultan (bersama-sama).

(2) $\mathrm{H}_{\mathrm{a}}: \mathrm{b}_{1}, \mathrm{~b}_{2}, \mathrm{~b}_{3},>0$, berarti terdapat pengaruh antara gaya kepemimpinan transformasional (X1), kompensasi (X2), dan budaya organisasi (X3), terhadap produktivitas kerja karyawan (Y) secara simultan (bersama-sama).

\section{c. Koefisien Determinasi}

Uji ketepatan perkiraan $\left(\mathrm{R}^{2}\right)$ dilakukan untuk mendeteksi ketepatan yang paling baik dalam analisis regresi. Uji ini dengan 
membandingkan besarnya nilai koefisiensi determinan $\left(\mathrm{R}^{2}\right)$ dan jika $\mathrm{R}^{2}$ semakin besar mendekati 1 (satu) maka model semakin tepat.

\section{ANALISIS DATA}

\section{a. Uji Validitas}

Uji Validitas dilakukan untuk mengetahui tingkat kevalidan indikator yang digunakan atau indikator sebagai alat ukur variabel. Dalam penelitian ini, uji validitas menggunakan Scale (Corrected Item Total Colleration). Nilai korelasi (r) hasil perhitungan kemudian dikonsultasikan dengan nilai $\mathrm{r}$ yang terdapat pada tabel. Jika $r$ hitung $>r$ tabel maka item pertanyaan tersebut adalah valid dan jika $\mathrm{r}_{\text {hitung }}<\mathrm{r}$ tabel maka pertanyaan tersebut tidak valid dan harus dikeluarkan dari instrument. Nilai $\mathrm{r}_{\text {tabel }}$ untuk jumlah responden $(\mathrm{N})$ sebanyak 66 dengan df $=64(\mathrm{n}-2)$, pada taraf signifikansi $\alpha=5 \%$ adalah 0,2423. Penghitungan validitas yang digunakan dalam penelitian ini menggunakan program SPSS versi 18.0 dan hasilnya dapat dilihat pada tabel dibawah ini:

\section{Tabel 2}

Hasil Pengujian Validitas

\begin{tabular}{|c|l|c|c|c|}
\hline No & \multicolumn{1}{|c|}{ Indikator } & $\mathbf{r}_{\text {hitung }}$ & $\mathbf{r}_{\text {tabel }}$ & Keterangan \\
\hline $\mathbf{1}$ & \multicolumn{3}{|c|}{ Gaya Kepemimpinan Transformasional } \\
\hline & Pertanyaan No. 1 & 0,246 & 0,2423 & Valid \\
\hline & Pertanyaan No. 2 & 0,353 & 0,2423 & Valid \\
\hline & Pertanyaan No. 3 & 0,369 & 0,2423 & Valid \\
\hline & Pertanyaan No. 4 & 0,360 & 0,2423 & Valid \\
\hline & Pertanyaan No. 5 & 0,295 & 0,2423 & Valid \\
\hline $\mathbf{2}$ & \multicolumn{3}{|c|}{ Kompensasi } \\
\hline & Pertanyaan No. 1 & 0,709 & 0,2423 & Valid \\
\hline & Pertanyaan No. 2 & 0,745 & 0,2423 & Valid \\
\hline & Pertanyaan No. 3 & 0,668 & 0,2423 & Valid \\
\hline $\mathbf{3}$ & \multicolumn{3}{|c|}{ Budaya organisasi } \\
\hline & Pertanyaan No. 1 & 0,417 & 0,2423 & Valid \\
\hline & Pertanyaan No. 2 & 0,453 & 0,2423 & Valid \\
\hline & Pertanyaan No. 3 & 0,479 & 0,2423 & Valid \\
\hline & Pertanyaan No. 4 & 0,639 & 0,2423 & Valid \\
\hline & Pertanyaan No. 5 & 0,465 & 0,2423 & Valid \\
\hline
\end{tabular}




\begin{tabular}{|c|c|c|c|c|}
\hline No & \multicolumn{1}{|c|}{ Indikator } & $\mathbf{r}_{\text {hitung }}$ & $\mathbf{r}_{\text {tabel }}$ & Keterangan \\
\hline $\mathbf{4}$ & \multicolumn{3}{|c|}{ Produktivitas Kerja Karyawan } \\
\hline & Pertanyaan No. 1 & 0,410 & 0,2423 & Valid \\
\hline & Pertanyaan No. 2 & 0,469 & 0,2423 & Valid \\
\hline & Pertanyaan No. 3 & 0,600 & 0,2423 & Valid \\
\hline
\end{tabular}

Dari hasil pengujian validitas yang ditampilkan pada tabel diatas menyatakan bahwa hasil dari masing-masing butir pertanyaannya memiliki $r_{\text {hitung }}>r_{\text {tabel }}$ yang disyaratkan yaitu 0,2423. Dengan demikian semua butir pertanyaan/ indikator dari variabel Gaya Kepemimpinan Transformasional, Kompensasi, Budaya Organisasi dan Produktivitas Kerja Karyawan dinyatakan valid.

\section{b. Uji Reliabilitas}

Uji Reliabilitas untuk mengetahui apakah indikator yang digunakan dapat dipercaya atau handal sebagai alat ukur variabel. Apabila nilai cronbach's alpha $(\alpha)$ suatu variabel $>0,60$ maka indikator yang digunakan oleh variabel tersebut reliabel, sedangkan bila nilai cronbach's alpha $(\alpha)$ suatu variabel $<0,60$ maka indikator yang digunakan oleh variabel tersebut tidak reliabel. Penghitungan reliabilitas yang digunakan dalam penelitian ini menggunakan program SPSS versi 18.0 dan hasilnya dapat dilihat dibawah ini:

\section{Tabel 3}

Hasil Uji Reliabilitas

\begin{tabular}{|c|l|c|c|c|}
\hline No & \multicolumn{1}{|c|}{ Variabel } & $\begin{array}{c}\text { Cronbach } \\
\text { Alpha }\end{array}$ & $\begin{array}{c}\text { Alpha } \\
\text { Pembanding }\end{array}$ & Keterangan \\
\hline 1 & $\begin{array}{l}\text { Gaya Kepemimpinan } \\
\text { Transformasional }\end{array}$ & 0.741 & 0,6 & Reliabel \\
\hline 2 & Kompensasi & 0.865 & 0,6 & Reliabel \\
\hline 3 & Budaya Organisasi & 0.771 & 0,6 & Reliabel \\
\hline 4 & Produktivitas Kerja & 0.819 & 0,6 & Reliabel \\
\hline
\end{tabular}

Pada tabel diatas menunjukkan bahwa nilai cronbach's alpha semua variabel di atas 0,60 sehingga dapat disimpulkan indikator yang digunakan oleh variabel Gaya Kepemimpinan Transformasional, Kompensasi, Budaya 
Organisasi dan Produktivitas Kerja Karyawan dapat dipercaya atau handal untuk digunakan sebagai alat ukur variabel.

\section{c. Analisa Regresi Berganda}

Analisis ini digunakan untuk mengetahui besarnya pengaruh variabelvariabel independen terhadap variabel dependen/terikat, baik secara individual maupun secara bersama-sama.

\section{Tabel 4}

Coefficients $^{a}$

\begin{tabular}{|l|r|r|r|r|r|}
\hline \multirow{2}{*}{ Model } & \multicolumn{2}{|c|}{$\begin{array}{c}\text { Unstandardized } \\
\text { Coefficients }\end{array}$} & $\begin{array}{c}\text { Standardized } \\
\text { Coefficients }\end{array}$ & \\
\cline { 2 - 4 } & \multicolumn{1}{|c|}{$\mathrm{B}$} & Std. Error & \multicolumn{1}{|c|}{ Beta } & \multicolumn{1}{c|}{$\mathrm{t}$} & \multicolumn{1}{|c|}{ Sig. } \\
\hline (Constant) & -.812 & 1.990 & & -.408 & .685 \\
X1 & .063 & .093 & .077 & .673 & .504 \\
X2 & .157 & .139 & .165 & 1.129 & .263 \\
X3 & .393 & .125 & .434 & 3.153 & .002 \\
\hline
\end{tabular}

a. Dependent Variable: $Y$

Sumber: Hasil olah data dengan SPSS versi 18.0

Berdasarkan tabel diatas yang diperoleh dari hasil pengolahan dan komputerisasi dengan menggunakan program SPSS versi 18.0 maka diperoleh persamaan regresi berganda sebagai berikut:

$$
Y=-0,812+0,063 X_{1}+0,157 X_{2}+0,393 X_{3}
$$

Persamaan regresi diatas dapat dijelaskan sebagai berikut:

a. Nilai konstan sebesar $-0,812$ berarti bahwa tanpa adanya variabel $\mathrm{X}_{1}$ (Gaya Kepemimpinan Transformasional), $\mathrm{X}_{2}$ (Kompensasi), $\mathrm{X}_{3}$ (Budaya Organisasi) maka besarnya Y (Produktivitas Kerja Karyawan) sebesar $-0,812$ satuan.

b. Koefisien regresi untuk variabel $\mathrm{X}_{1}$ (Gaya Kepemimpinan Transformasional) sebesar 0,063 menyatakan bahwa variabel Gaya Kepemimpinan Transformasional mempunyai pengaruh positif terhadap Produktivitas Kerja Karyawan. Apabila $\mathrm{X}_{1}$ (Gaya 
Kepemimpinan Transformasional) naik satu satuan maka variabel Produktivitas Kerja Karyawan akan naik sebesar 0,063 satuan.

c. Koefisien regresi untuk variabel $\mathrm{X}_{2}$ (Kompensasi) sebesar 0,157 menyatakan bahwa variabel Kompensasi mempunyai pengaruh positif terhadap Produktivitas Kerja Karyawan. Apabila $\mathrm{X}_{2}$ (Kompensasi) naik satu satuan maka variabel Produktivitas Kerja Karyawan akan naik sebesar 0,157 satuan.

d. Koefisien regresi untuk variabel $\mathrm{X}_{3}$ (Budaya organisasi) sebesar 0,393 menyatakan bahwa variabel Budaya Organisasi mempunyai pengaruh positif terhadap Produktivitas Kerja Karyawan. Apabila $\mathrm{X}_{3}$ (Budaya Organisasi) naik satu satuan maka variabel Produktivitas Kerja Karyawan akan naik sebesar 0,393 satuan.

\section{d. Uji Hipotesis}

Tabel 5

Hasil Uji t

\begin{tabular}{|c|c|c|c|c|}
\hline No & Variabel & $\mathbf{t}$ hitung & $\mathbf{t}_{\text {table }}$ & $\mathbf{H}$ \\
\hline 1 & $\begin{array}{c}\text { Gaya Kepemimpinan } \\
\text { Transformasional }\end{array}$ & 0,673 & 1,9990 & $\mathrm{H} 1$ \\
\hline 2 & Kompensasi & 1,129 & 1,9990 & $\mathrm{H} 2$ \\
\hline 3 & Budaya Organisasi & 3,153 & 1,9990 & $\mathrm{H} 3$ \\
\hline
\end{tabular}

Sumber: Hasil olah data dengan SPSS versi 18.0

Tabel hasil perhitungan uji $t$ dapat dijelaskan sebagai berikut:

\section{Pengaruh Gaya Kepemimpinan Transformasional Terhadap Produktivitas Kerja Karyawan (H1)}

Dari hasil perhitungan diperoleh nilai $\mathrm{t}$ hitung untuk variabel Gaya Kepemimpinan Transformasional adalah sebesar 0,673 dan dengan menggunakan taraf signifikasi sebesar 5\% diperoleh $t$ tabel sebesar 1,9990 yang berarti bahwa nilai $\mathrm{t}$ hitung lebih kecil dari $\mathrm{t}_{\text {tabel }}$ yaitu $0,673<1,9990$. Nilai signifikasi t kurang dari 5\% (0,504) menandakan bahwa Gaya Kepemimpinan Transformasional tidak mempunyai pengaruh yang signifikan terhadap Produktivitas Kerja Karyawan Perhimpunan BMT Indonesia di Kabupaten Semarang, karena $t$ hitung $<\mathrm{t}$ tabel, maka Ho diterima yang berarti pernyataan hipotesis 1 penelitian bahwa tidak terdapat pengaruh signifikan Gaya 
Kepemimpinan Tranformasional terhadap Produktivitas Kerja Karyawan pada Perhimpunan BMT Indonesia di Kabupaten Semarang.

\section{Pengaruh Kompensasi Terhadap Produktivitas Kerja Karyawan (H2)}

Dari hasil perhitungan diperoleh nilai $t$ hitung untuk variabel Kompensasi adalah sebesar 1,129 dan dengan menggunakan taraf signifikasi sebesar 5\% diperoleh $t_{\text {tabel }}$ sebesar 1,9990 yang berarti bahwa nilai thitung lebih kecil dari $\mathrm{t}_{\text {tabel }}$ yaitu $1,129<1,9990$. Nilai signifikasi $\mathrm{t}$ kurang dari $5 \%(0,263)$ menandakan bahwa Kompensasi tidak mempunyai pengaruh yang signifikan terhadap Produktivitas Kerja Karyawan Perhimpunan BMT Indonesia di Kabupaten Semarang. Karena t hitung < t tabel, maka Ho diterima yang berarti pernyataan hipotesis 2 penelitian bahwa tidak terdapat pengaruh signifikan kompensasi secara terhadap Produktivitas Kerja Karyawan Perhimpunan BMT Indonesia di Kabupaten Semarang.

Pengaruh Budaya Organisasi terhadap Produktivitas Kerja Karyawan (H3)

Dari hasil perhitungan diperoleh nilai $\mathrm{t}$ hitung untuk variabel Budaya Organisasi adalah sebesar 3,153 dan dengan menggunakan taraf signifikasi sebesar 5\% diperoleh $t_{\text {tabel }}$ sebesar 1,9990 yang berarti bahwa nilai $t$ hitung lebih besar dari $t_{\text {tabel }}$ yaitu 3,153>1,9990. Nilai signifikasi t kurang dari 5\% $(0,000)$ menandakan bahwa Budaya Organisasi mempunyai pengaruh yang signifikan terhadap Produktivitas Kerja Karyawan pada Perhimpunan BMT Indonesia di Kabupaten Semarang. Dapat dijelaskan bahwa Budaya Organisasi berpengaruh signifikan. Hal ini dapat dilihat dari sebagian besar responden yang menjawab sangat setuju, artinya Budaya Organisasi mempengaruhi Produktivitas Kerja Karyawan.

\section{Pengaruh pengaruh Gaya Kepemimpinan Transformasional,} Kompensasi, Budaya Organisasi dan Produktivitas Kerja Karyawan Terhadap Produktivitas Kerja Karyawan (H4)

Pengaruh antara Gaya Kepemimpinan Transformasional $\left(\mathrm{X}_{1}\right)$, Kompensasi $\left(\mathrm{X}_{2}\right)$ dan Budaya Organisasi $\left(\mathrm{X}_{3}\right)$ terhadap Produktivitas Kerja Karyawan (Y) diuji dengan menggunakan Uji F (pengujian secara simultan). 
Untuk menguji signifikasi dan melihat keberhasilan Uji $F$ dilakukan dengan membandingkan $\mathrm{F}$ hitung dan $\mathrm{F}$ tabel. Dengan perhitungan menggunakan program SPSS versi 18.0 dapat diketahui hasil sebagai berikut:

Tabel 6

ANOVA ${ }^{b}$

\begin{tabular}{|l|r|r|r|c|c|}
\hline \multicolumn{1}{|c|}{ Model } & Sum of Squares & df & Mean Square & F & Sig. \\
\hline $1 \quad$ Regression & 63.432 & 3 & 21.144 & 11.142 & $.000^{\mathrm{a}}$ \\
Residual & 117.659 & 62 & 1.898 & & \\
Total & 181.091 & 65 & & & \\
\hline
\end{tabular}

a. Predictors: (Constant), X3, X1, X2

b. Dependent Variable: $Y$

Sumber: Hasil olah data dengan SPSS versi 18.0

Berdasarkan tabel diatas maka diperoleh Sig. F 0,000 < 0,05 dengan $\mathrm{F}_{\text {hitung }}>\mathrm{F}_{\text {tabel }}=11,142>2,75$. Ini berarti ketiga variabel yaitu Gaya Kepemimpinan Transformasional, Kompensasi dan Budaya Organisasi secara simultan berpengaruh signifikan terhadap Produktivitas Kerja Karyawan pada Perhimpunan BMT Indonesia di Kabupaten Semarang . .

\section{e. Koefisien Determinasi}

Koefisien determinasi digunakan untuk mengetahui kemampuan variabel independen dalam menjelaskan variabel depanden. Besarnya koefisien determinasi dapat dilihat pada adjusted $r$ square dan dinyatakan dalam presentase. Hasil koefisien determinasi antara Gaya Kepemimpinan Transformasional $\left(x_{1}\right)$, Kompensasi $\left(x_{2}\right)$, Budaya Organisasi $\left(x_{3}\right)$ terhadap Produktivitas Kerja Karyawan (y) Perhimpunan BMT Indonesia di Kabupaten Semarang dapat dilihat pada tabel berikut ini :

Tabel 7

\section{Koefisien Determinasi}

Model Summary

\begin{tabular}{|l|r|r|r|c|}
\hline Model & $\mathrm{R}$ & $\mathrm{R}$ Square & \multicolumn{1}{|c|}{$\begin{array}{c}\text { Adjusted R } \\
\text { Square }\end{array}$} & $\begin{array}{c}\text { Std. Error of the } \\
\text { Estimate }\end{array}$ \\
\hline 1 & $.592^{\mathrm{a}}$ & .350 & .319 & 1.378 \\
& & & & \\
\hline
\end{tabular}

a. Predictors: (Constant), X3, X1, X2

Sumber: Hasil olah data dengan SPSS versi 18.0 
Dari tabel diatas dapat diketahui nilai adjusted $r$ square sebesar 0,319 yang artinya variabel pengaruh Gaya Kepemimpinan Transformasional, Kompensasi dan Budaya Organisasi menjelaskan Produktivitas Kerja Karyawan pada Perhimpunan BMT Indonesia di Kabupaten Semarang sebesar 0,319 atau 31,90\%, sementara sisanya sebesar $100 \%-31,90 \%,=68,10 \%$, Produktivitas Kerja Karyawan Perhimpunan BMT Indonesia di Kabupaten Semarang dijelaskan oleh faktor lain diantaranya faktor konflik kerja, kepuasan kerja, promosi dan lain-lain.

\section{KESIMPULAN}

Berdasarkan uraian yang telah penulis sampaikan, maka penulis akan mengemukakan saran-saran dengan harapan dapat bermanfaat bagi perkembangan dan kemajuan perusahaan dimasa yang akan datang. Adapun saran-saran tersebut adalah:

1. Dari hasil penelitian ini dapat memberikan implikasi penting bagi manajemen sumber daya manusia pada Perhimpunan BMT Indonesia di Kabupaten Semarang dengan mengetahui bahwa gaya kepemimpinan transformasional tidak terlalu dipertimbangkan oleh karyawan, karena kemungkinan bahwa kepemimpinan belum memenuhi ekspektasi karyawan dalam hal peningkatan produktivitas kerja. Kompensasi juga kurang berpengaruh terhadap produktivitas kerja karyawan. Artinya, kompensasi juga merupakan variabel yang kurang dipertimbangkan oleh karyawan dalam aspek yang menimbulkan produktivitas kerja karyawan karena mungkin belum seperti yang diharapkan. Oleh karena itu, sebaiknya budaya organisasi pada Perhimpunan BMT Indonesia di Kabupaten Semarang dipertahankan dan ditingkatkan karena tingginya pengaruh budaya organisasi terhadap produktivitas kerja karyawan. Hal ini bisa dengan membuat konsep budaya organisasi yang lebih kuat dan baik lagi.

2. Penelitian ini masih banyak mempunyai kekurangan baik di pembahasan maupun metodologi sehingga diperlukan perbaikan selanjutnya. Oleh karena itu, diharapkan penelitian selanjutnya dapat lebih memilih varibel 
atau menambahkan variabel lain, seperti konflik kerja, kepuasan kerja, motivasi kerja dan lain - lain.

\section{DAFTAR PUSTAKA}

Arikunto, Suharsimi. 2006. Prosedur Penelitian Suatu Pendekatan Praktik. Jakarta : Rineka Cipta

Azhar Arsyad. 2003. Media Pembelajaran. Jakarta : Rajawali Pers

Efendi, Marihot Tua. 2007. Manajemen Sumber Daya Manusia .Jakarta, Grasindo

Hasan, Iqbal. 2004. Analisis Data Penelitian dengan Statistik. Jakarta : Bumi Aksara

Hasan, Ali. 2009. MANAJEMEN BISNIS SYARI'AH Kaya di Dunia Terhormat di Akhirat, Yogyakarta: Pustaka Pelajar

Hasibuan, M. 2007, Manajemen Sumber Daya Manusia, Jakarta : Bumi Aksara

Heizer, Jay\& Barry Render. 2009. Manajemen Operasi Buku 1 Edisi 9. Jakarta: Salemba Empat

Iqbal, Hasan. (2002). Pokok-Pokok Materi Metodologi Penelitian Dan Aplikasinya, Edisi Pertama, Jakarta : Ghalia Indonesia

Martoyo, Susilo. 2000. Manajemen Sumber Daya Manusia Edisi 4. Yogyakarta: BPFE

Marzuki, C. 1999. Metodologi Riset. Jakarta: Erlangga

Moeljono, Djokosantoso. 2003. Budaya Korporat dan Keunggulan Korporasi, "Pengembangan Budaya Korporasi.” Jakarta: PT Elex Media Komputindo

Pabundu, Tika. 2006. Budaya Organisasi dan Peningkatan Kinerja Perusahaan, Jakarta: PT Bumi Aksara

Rivai, Veithzal dan Ella Jauvani. 2009. Manajemen Sumber Daya Manusia untuk Perusahaan. Jakarta: Rajawali Pers

Robbins SP, dan Judge. 2007. Perilaku Organisasi. Jakarta: Salemba Empat

Rivai, Veithzal. 2009. Manajemen Sumber Daya Manusia Untuk Perusahaan Dari Teori ke Praktik. Jakarta: Raja Grafindo Persada

Supramono, 2001. Metode Penelitian Bisnis. Salatiga : Fakultas Ekonomi Universitas Kristen Satya Wacana Press 
Simamora, Henry. 2004. Manajemen Sumber Daya Manusia. Edisi Ke-3. Yogyakarta: STIE YKPN

Soeratno, Lincolin Arsyad. 2003. Metodologi Penelitian : Untuk Ekonomi dan bisnis. Yokyakarta: YKPN

Sugiyono 2006. Metode Penelitian Kuantitatif, Kualitatif, dan R\&D, Bandung: Alfabeta , 2006. Metode Penelitian Bisnis, Bandung: Alfabeta

S. Panggabean, Mutiara. Manajemen Sumber Daya Manusia, Ghalia Indonesia, Bogor

Sinungan, Muchdarsyah. 2003. Manajemen Sumber Daya Manusia. Jakarta : Bumi Aksara. (Sinungan, 2003, p. 24-25)

Sukandarrumidi. 2006. Metode Penelitian, Petunjuk Praktis Untuk Peneliti Pemula. Gadjah Mada University Press, Yogyakarta

Tjiptono, F. 2002. Manajemen Jasa, Edisi II. Cetakan ketiga, Penerbit Andi Offset, Yogyakarta.

Umar, Husein. 2002. Metode Riset Bisnis, PT.Gramedia Pustaka Utama, Jakarta

Wirawan. 2007. Budaya dan Iklim Organisasi Teori Aplikasi dan Penelitian. Jakarta: Salemba Empat. 